\title{
DOG1, alpha-amylase and p63 expression in acinic cell carcinoma of salivary gland; immunohistochemical, clinical and radiological study
}

Ihab Shafek Atta ${ }^{*}$ and Fahd Nasser Al Qahtani ${ }^{2}$

*Correspondence: Attaihab@yahoo.com

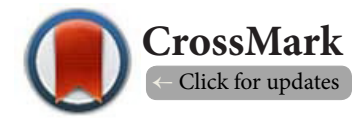

'Department of Pathology, Faculty of medicine, Al-Azhar university (Assuit branch), Egypt.

${ }^{2}$ Department of Radiology, Faculty of Medicine, Albaha university, Saudi Arabia.

\begin{abstract}
Introduction: Identification of serous acinar differentiation is the basic step for the diagnosis of acinic cell carcinoma (ACC). a-amylase was described to be specific for normal acinar cell but its affinity to malignant counterpart is being contentious. Recently discovered marker anoctamin (DOG1) specific for diagnosis of GISTs has been reported for its efficacy to stain the malignant acinar cells and so, it is being of value in ACC diagnosis. On the other hand, negativity of acinar cells to basal cell marker as p63 will give more pronouncement to ACC diagnosis.
\end{abstract}

Objectives: The study were designed to scrutinize the expression of recent marker DOG1 versus a-amylase in ACC diagnosis. Also to correlate between clinical, radiological, histopathological and immunohistochemical findings in ACC cases.

Material and methods: Fourteen cases of ACC were obtained and stained immunohistochemically for DOG 1, a-amylase and p63. Clinical data as well as radiological findings were obtained from the patients' file to form correlation with immunostaining results.

Results: All ACCs (100\%) revealed positivity toward DOG1 staining, 6 (44\%) cases out of 14 showed a-amylase positivity, and 1 case (7\%) showed focal positivity for p63. No significant correlation was found between clinical, radiological and immunostaining results. Significant correlation was obtained between results of DOG 1 and $a$-amylase with p-value $=0.034$, also significant correlation was obtained between DOG 1 and p63 with p-value $=0.02$. On the other hand, no significant correlation was obtained between results of both a-amylase and p63 with p-value $=0.546$.

Conclusion: DOG 1 has a higher efficacy in the diagnosis of ACC than a-amylase and must be used especially for cases with some conflicts as poor tissue sampling or suspicious cases with other carcinomas especially with carcinomas of clear cell features or having a vacuolated cytoplasm.

Keywords: DOG 1, a-amylase, p63, acinic cell carcinomas, salivary gland tumors

\section{Introduction}

Acinic cell carcinoma (ACC) is a low grade malignant tumor and represents about $17 \%$ of all salivary tumors. It has more predilections to parotid gland with lesser extent to minor salivary gland as well as parotid lymph node [1]. Women are commonly affected and many factors as genetic, familial and radiation are considered the main risk factors for its development $[2,3]$.

Histopathological examination revealed differentiation towards acinar cells. Variable microscopic variants and patterns are seen as solid, papillary, cystic, microcystic, follicular and lymphoid. In addition to these variants, cells in ACC may be granular, clear or vacuolated. Overall, irrespective of cell type, scant mitoses are generally seen $[4,5]$.

Recognition of acinar cell differentiation is the basic step of ACC diagnosis [6]. For this purpose, a-amylase was widely used to highlight these acinar cells. Conversely, a positivity of acinar cells for a-amylase appeared to be restricted to normal acinar cells with low affinity to its malignant counterpart. This motivated the researches to investigate about a novel marker that is being more specific and expressed by malignant acinar cells until one of researchers found positivity of malignant acinar cells to DOG1 that was applied initially for diagnosis of 
Atta et al. Journal of Histology \& Histopathology 2015,

gastrointestinal stromal tumors (GISTs) [6].

Anoctamin-1 (DOG1,TMEM16a) or (ANO1) is a calcium-activated chloride channel protein that resides on the chromosome 11q13. It was initially described in GISTs $[7,8]$ but now known to be expressed in a variety of normal and tumor tissues including salivary tissue [9]. Chromosomal studies revealed amplification in the region 11q13 that the ANO1 harbor. This yield in DOG1 over-expression that was seen in the varieties of tumor, but its amplification in salivary gland tumors, especially those originating from acinic cell has not been proved $[10,11]$. Several studies revealed that DOG1 has an essential role in the secretory function of salivary gland rather than its presence [12-14].

p63 protein (p63) is a nuclear protein, a member of the TP53 family and act as a transcription factor that plays a critical role in the growth and development of many epithelial organs $[15,16]$. It is confined to basal cells of squamous epithelia as well as basal cells/myoepithelial cells in breast, sweat glands, prostate and salivary glands $[17,18]$. However, the differential role and function of the main p63 gene in the development and biological features of salivary gland tumors remain unknown $[19,20]$.

Our presenting study was aimed to in-vestigate the expression of a recent marker DOG1 versus a-amylase in association with p63 in ACC. The goals of this investigation were to find a more sensitive marker that help in reaching the accurate diagnosis, especially for cases with some conflicts as poor tissue sampling or suspicious cases with other carcinomas as carcinomas with clear cell features, and finally was to correlate between clinical, radiological and immunohistochemical findings in ACC cases.

\section{Material and methods}

Fourteen formalin-fixed, paraffin-embedded specimens that had been diagnosed previously as ACC were collected from archival material from Al-Baha province' hospitals (King Fahd and Bilgrorashi) Hospitals, Saudia Arabia. These cases were obtained from period between 2000-2014. In each case, clinical data including radiographic findings were obtained from the patients' file as well as from reference sheet. The clinical data obtained included the age and clinical presentation. All specimens were collected after taking written approval from both health manager of both hospital under number 235/2014 and 196/2014 respectively.

\section{For H\&E staining}

Tissue samples were routinely fixed in $10 \%$ formalin, embedded in paraffin, cut into $4 \mu \mathrm{m}$ thick sections and stained with hematoxylin and eosin stain (H\&E). All H\&E stained sections were reexamined by two histopathologists before immunohistochemical staining.

\section{Immunohistochemical staining}

Immunohistochemical procedures were run on consistently practiced, formalin- locked, paraffin rooted tissue.

For DOG 1: Immunohistochemical staining was done using DOG1 (IgG, rabbit monoclonal antibody SP31, Ventana, USA, with dilution 1:50). For a-amylase: Immunohistochemical staining was performed using Anti-a Amylase antibody (Abcam, USA) (Mouse monoclonal to $a$-amylase ab54765, concentration $100 \mu \mathrm{g}$ at $0.5 \mathrm{mg} / \mathrm{ml}$, isotype lgG2a, monoclonal, of kappa light chain) the antibody was diluted $1 / 50$ and Labeling was performed using the DAB detection kit [21]. For P63: immunohistochemical procedures were done by using the 4A4 anti-p63 antibody (Dako, Denmark, Code M7247). This antibody has the ability to identify all p63 isotypes.

For all markers, the following procedures were done; tissue specimens were cut into $4 \mu \mathrm{m}$, build up on poly-Llysine-immersed slides, were depareffinized, rehydrated, and put in microwave in $10 \mathrm{mmol} / \mathrm{L}$ citrate buffer at $\mathrm{pH} 6.0$ in a $750 \mathrm{~W}$ oven for 15 minutes. Slides were permitted to cool at room temperature for 30 minutes. The diluted antibody was preserved at room temperature for 2 hours in an automated Stainer (manufactured by BioGenex, San Ramon, CA, USA). Detection steps were completed by the instrument using the MultiLink-HRP kit (BioGenex). Peroxidase activity was localized using 3,3-diaminobenzidine or 3,3-diaminobenzidine-nickel chloride. Standardized development time periods allowed accurate comparison of all samples.

Evaluation of staining was considered as a regard cell type and percentage of stained cells. For DOG1 and a-amylase a positive staining was considered as cytoplasmic (dark for DOG1 and reddish brown for a-amylase) diffuse or granular staining for p63, distinct nuclear staining was only considered. The staining intensity was graded as negative, weak (focal apical cytoplasmic staining), or strong (diffuse strong cytoplasmic staining). Percent of positive cell less than 5 was considered negative and focal if more than 5 and less than $10 \%$, moderate between 10 and $50 \%$ and diffuse if more than $50 \%$ of cells showing positivity [6].

\section{Statistical analysis}

Chi-square test and Fisher's exact tests were used to compare the DOG1, a-amylase and $\mathrm{p} 63$ percentage and staining intensity data. $p$-values less than or equal to 0.05 were considered significant. The sensitivity of DOG1, a-amylase and p63 were calculated by calculation of percentage of positive cases to total ACC cases. Harvard Graphics was used for drawing figures. Computer software Statistical Package for the social science (SPSS) version 17 was used in the analysis of the presenting study.

\section{Results}

\section{Analysis of clinical data}

The age of the presented cases was ranged from 16-62 years, with mean $\pm S D ; 46 \pm 2.1$. All cases were presented by infraauricular mass. 3 out of 14 cases were presented with pain, 1 case was presented by facial nerve palsy. 2 cases showed cervical 
lymph node metastasis. Staging of ACC was done according to AJCC [22] tumor stage and was as follows; $80 \%, 18 \%$, and $2 \%$ in stages I, II, and IV, respectively. 12 out of 14 cases were treated by surgical excision and two cases were treated by total excision followed by radiotherapy.

\section{Radiographic findings}

From patients' file, CT scan was done in 12 cases out of 14 and obtained information appeared that most of lesions were seen in the superficial lobe of the parotid. 8 cases revealed solid component, 2 cases were cystic and 2 cases showed mixtures of solid and cystic areas. All solid masses in the parotid gland showed nonspecific appearance, hypoattenuating regions of central necrosis, irregular enhancing solid component, which appeared as microcyst, hemorrhage, or necrosis on pathologic examination. No intratumoral calcifications were seen, two cases showed metastatic lymphadenopathy on imaging and histology study (Figure 1A and Table 2).

An MRI was done in all cases and revealed that 10 cases were solid lesions, 2 cases were cyctic and 2 cases were mixed solid/cystic lesions. All cases showed nonspecific appearance, 2 cases with cystic lesions were T2 hyperintense, while 10 cases with solid and 2 cases of mixed lesions were mildly $T 2$ hyperintense, well-marginated and showed enhancement on the post-contrast sequence (Figure 1 B and Table 2).

\section{Histopathological results}

All histopathological slides were re-examined by two pathologists and all cases were diagnosed as ACC of different histologic patterns mainly papillary (Figure $2 A$ ) and solid pattern (Figure 2B).

Results of DOG1, $\alpha$-amylase and p63 immunostaining Results of DOG 1 revealed that all cases of ACC showed DOG 1 staining. Of the positive cases; 6 cases (43\%) showed diffuse staining as more than $50 \%$ of cells showed positivity, 7 cases (50\%) showed moderate positivity and 1 case $(7 \%)$ revealed weak positivity for DOG1. The weak positivity in this case was

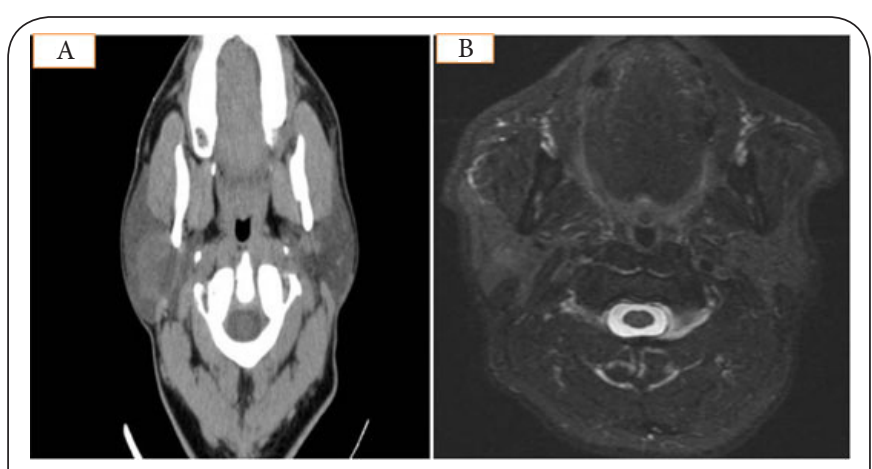

Figure 1. (A) CT of ACC showing nonspecific appearance, hypoattenuating regions of central necrosis, irregular enhancing solid component. (B) MRI of ACC showing cystic/necrotic and solid component, well-marginated mass.

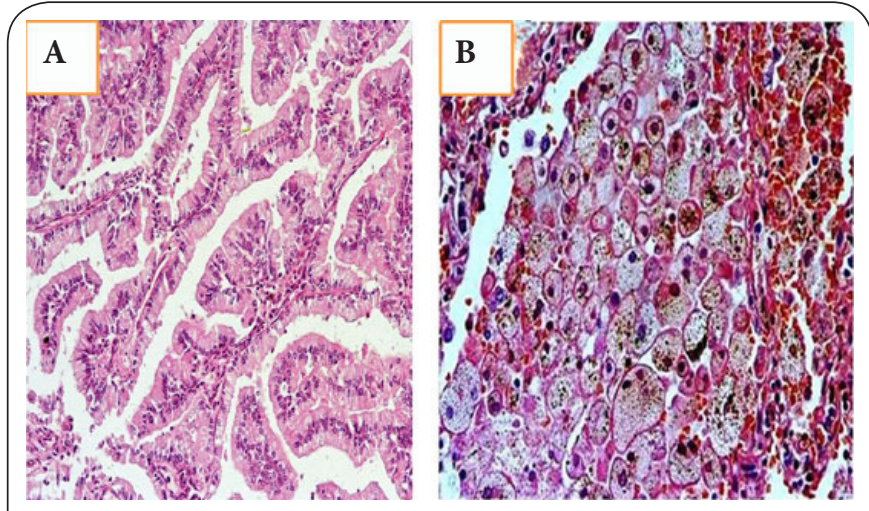

Figures 2. (A) A case of acinic cell carcinoma showing papillary pattern showing cells with basaly located nuclei and slightly basophilic cytoplasm (Hematoxylin and Eosin stain (H\&E) stain) (x100). (B) A case of acinic cell carcinoma showing solid pattern showing cells with central to eccentric nuclei and basophilic granular cytoplasm (Hematoxylin and Eosin stain (H\&E) stain) (x400).

due to the presence of more vacuolated cells. The staining was membranous and cytoplasmic, more intense in acinar cell types (Figure 3A) than intercalated duct (Figures 3B and 6), more intense in compact than vacuolated cells and more localized in an apical part of serous acini (Tables 1,3).

Alpha-amylase revealed positivity in 6 out of 14 ACC cases $(43 \%)$ and negativity in 8 cases (57\%). Of the positive cases, 3 cases showed diffuse staining, 2 cases with moderate positivity and one case was weak (Figures 4A-4C and 6) (Table 1,3).

Results of $p 63$ revealed that 13 out of 14 (93\%) of ACC cases were completely negative for p63 staining, while one case (7\%) showed focal positivity (Figures 5A,5B and 6) (Tables 1,3).
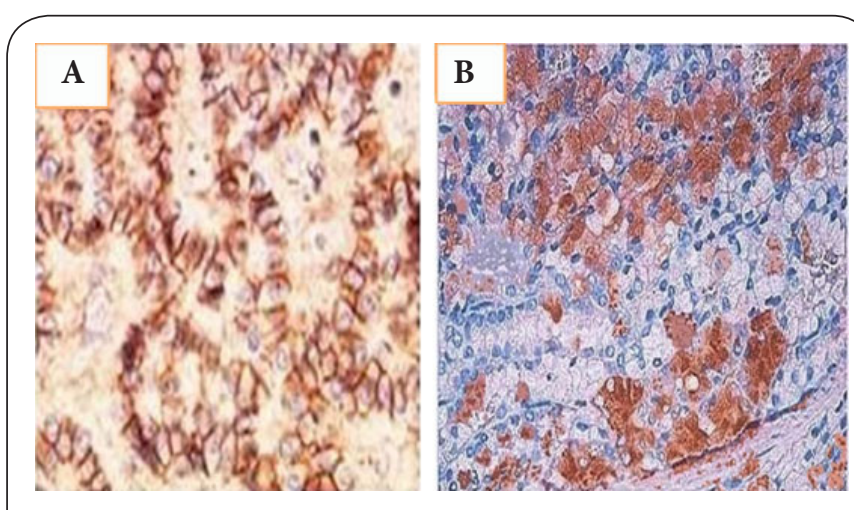

Figure 3. (A) A case of acinic cell carcinoma showing strong membranous positivity staining of acinar cells for DOG1 antibody immunostain (anti DOG1, rabbit monoclonal antibody, 3,3'-diaminobenzidine (DAB) (x200). (B) A case of acinic cell carcinoma showing strong cytoplasmic positivity staining of intercalated duct cells for DOG1 antibody immunostain (more than $50 \%$ of tumor cells were positive for DOG1 antibody (anti DOG1, rabbit monoclonal antibody, 3,3'-diaminobenzidine (DAB) $(x 100)$. 
Atta et al. Journal of Histology \& Histopathology 2015,

http://www.hoajonline.com/journals/pdf/2055-091X-2-13.pdf

doi: 10.7243/2055-091X-2-13

As regards results obtained for 3 markers, we found one case showed positivity for all markers, 5 cases were DOG $1+/ a-$ amylase+/p63- and 8 cases showed DOG1+/a-amylase -/ p63- (Table 3).

Sensitivity of DOG 1 staining for ACC is $100 \%$, of a-amylase $44 \%$, while the sensitivity of p63 immunostaining for ACC cases is 7\%.
Significant correlation was obtained between results of DOG1 and $a$-amylase with $p$-value $=0.034$, also significant correlation was obtained between DOG1 and p63 with p-value $=0.02$, on the other hand, no significant correlation was obtained between results of both $a$-amylase and $p 63$ with $p$-value $=$ 0.546 (Table 1).

Table 1. Correlation between DOG 1, a-amylase and p63 expression in ACC cases.

\begin{tabular}{|c|c|c|c|c|c|c|}
\hline \multirow[t]{2}{*}{ Lesion } & \multirow{2}{*}{$\begin{array}{l}\text { Number of } \\
\text { positive cases }\end{array}$} & \multicolumn{3}{|c|}{ Differential positivity count and its percentages } & \multirow{2}{*}{\multicolumn{2}{|c|}{ Negative p-value }} \\
\hline & & Focal (+) & Moderate $(++)$ & Strong $(+++)$ & & \\
\hline DOG 1 & 14 & $1(7 \%)$ & $7(50 \%)$ & $6(43 \%)$ & 0 & \multirow{3}{*}{$\begin{array}{l}\text { Correlation between results of DOG } 1 \text { and } \\
\alpha \text {-amylase }=0.034 \text { (significant), between } \\
\text { DOG } 1 \text { and p63 }=0.021 \text { (significant), } \\
\text { between alpha-amylase and p63 } \\
\text { p-value }=0.546 \text { (insignificant) }\end{array}$} \\
\hline$\alpha$-amylase & $6(44 \%)$ & $1(7 \%)$ & $2(14 \%)$ & $3(22 \%)$ & $8(56 \%)$ & \\
\hline P63 & 1 & $1(7 \%)$ & $0(0 \%)$ & $0(0 \%)$ & $13(93 \%)$ & \\
\hline
\end{tabular}

Table 2. Reactivity of cases to immunostains in relation to solid/cystic appearance in MRI findings.

\begin{tabular}{lllllllllll}
\hline MRI findings & \multicolumn{9}{c}{ DOG1 } & \multicolumn{3}{c}{$\boldsymbol{\alpha}$-amylase } & \multicolumn{2}{c}{ P63 } \\
\hline & -ve & Focal & Moderate & Strong & -ve & Focal & Moderate & Strong & -ve & Focal \\
\hline Solid & 0 & 1 & 6 & 2 & 7 & 1 & 1 & 2 & 13 & 1 \\
Cystic & 0 & 0 & 0 & 2 & 1 & 0 & 1 & 0 & 0 & 0 \\
Mixed & 0 & 0 & 0 & 2 & 0 & 0 & 0 & 1 & 0 & 0 \\
\hline
\end{tabular}

Table 3. Results of studied cases according to the three markers used.

\begin{tabular}{ll}
\hline Immunostain & Number and Percent \\
\hline DOG1+/a-amylase+/p63+ & $1(7 \%)$ \\
DOG1+/a-amylase+/p63- & $5(36 \%)$ \\
DOG1+/a-amylase-/p63- & $8(57 \%)$ \\
\hline
\end{tabular}
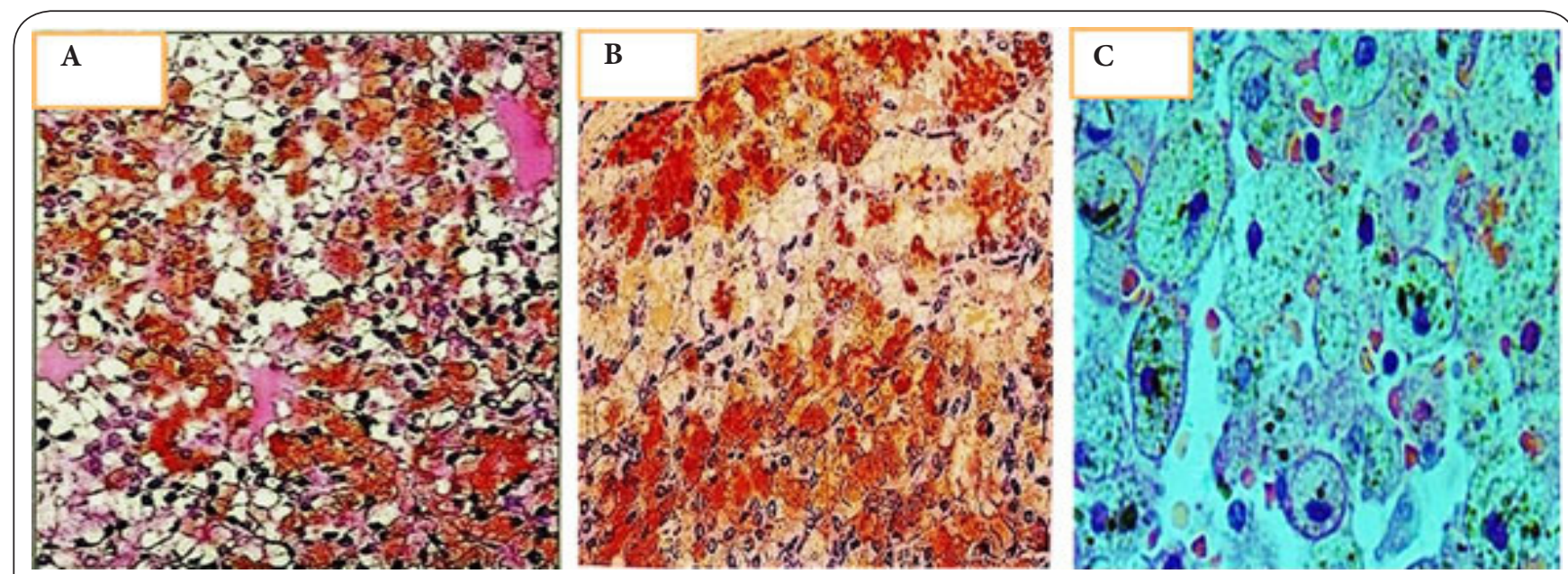

Figure 4. (A) A case of acinic cell carcinoma showing moderate positivity of acinar cells for $\alpha$-amylase antibody immunostain (less than $50 \%$ of tumor cells were positive for anti $\alpha$-amylase antibody) for anti $\alpha$-amylase mouse monoclonal antibody 3,3'-diaminobenzidine (DAB) (x200). (B) A case of acinic cell carcinoma showing strong positivity of intercalated duct cells for $\alpha$-amylase antibody (more than $50 \%$ of tumor cells were positive for anti $\alpha$-amylase antibody) (DAB) (x200). (C) A case of acinic cell carcinoma granular cytoplasm showing focal positivity for a-amylase antibody immunostain (DAB) (x1000). 


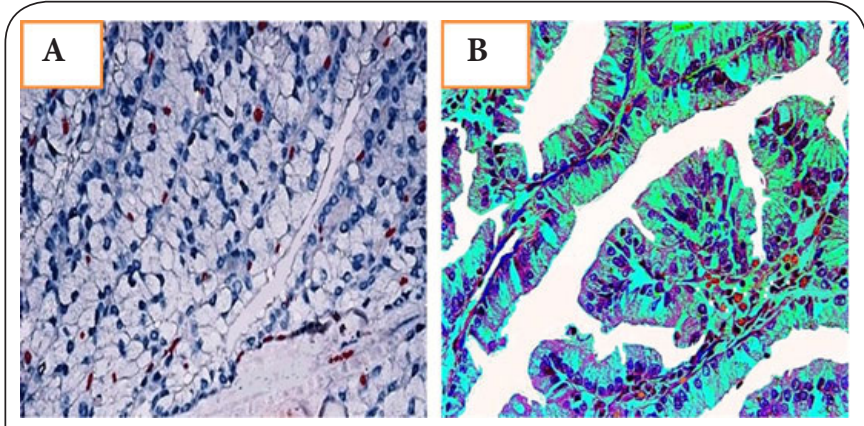

Figure 5. (A) A case of acinic cell carcinoma showing negativity of intercalated duct cells for $\mathrm{p} 63$ immunostaining (less than $5 \%$ of tumor cells were positive, some of these cells were abluminal cells), so it is considered as negative staining (anti p63 mouse monoclonal antibody, 3,3'-diaminobenzidine (DAB), (x100). (B) A case of acinic cell carcinoma of papillary pattern showing nuclear negativity of acinar cells to p63 antibody, some stromal cells give positive staining to p63 antibody are seen. (anti p63 mouse monoclonal antibody, 3,3'-diaminobenzidine (DAB), (x400).

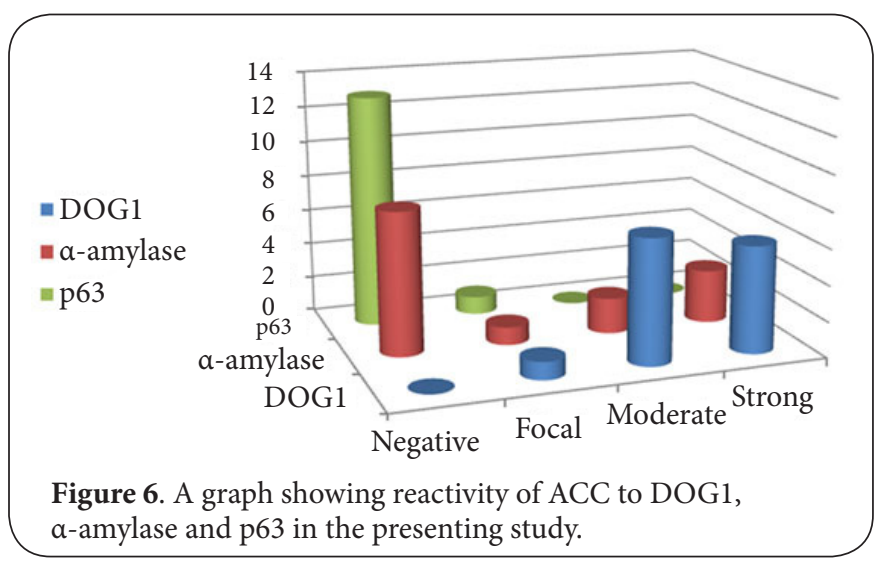

We noticed that the intensity of staining for DOG1 was marked in 2 cystic lesions than solid lesions, while for a-amylase, one case was moderate staining and another case was negative (Table 2). No significant correlations were obtained between intensity of staining of all markers and staging of tumor.

There was no significant correlation obtained between clinical findings (symptoms and signs) as well as radiological findings, $(p$-value $=0.564)$. Also no significant correlations were obtained between clinical findings with all of the results of immunostaining markers; clinical findings with DOG 1; $(p$-value $=0.547)$, with $a$-amylase $(p$-value $=0.643)$, with $\mathrm{p} 63=0.512$ ). Finally, no significant correlations were obtained between radiological findings and results of immunostaining markers; correlation of radiological findings with DOG1; ( $p$-value $=0.574)$, with $a$-amylase $p$-value $=0.659)$, with $\mathrm{p} 63=0.571)$.

\section{Discussion}

In the presenting study, we found the mean age of ACC cases was
46 years and the main presenting symptoms was painless infraauricular mass except in three cases in whom pain was present. Also one case was presented by facial palsy and 2 cases had cervical lymph node metastases. According to the AJCC [22], $80 \%$ of cases were in stage I while in $20 \%$ of cases were distributed among stage II and IV respectively. As regards these clinical findings, there was no unusual presentation of ACC cases in the presenting study and all these symptoms are in agreement with many previous studies $[\mathbf{5 , 2 3 , 2 4 ]}$. There was no significant correlation obtained between intensity of staining of all markers and staging of tumor. No previous studies did correlation between reactivity results of these markers and ACC staging. The intensity of DOG1 in addition to other markers with the staging of the tumor.

MRI findings revealed solid lesions of non specific appearance in 10 cases, cystic lesions in 2 cases and mixed lesions in 2 cases. Also, there was increased intensity to DOG 1 in cystic lesions than in solid lesions. This might be explained by the presence of tissue necrosis that reflect high grade malignancy, but this is not enough to say that 'the higher the grade, the higher the DOG1 intensity' due to the low number of cases subjected to the study. There was no significant correlation obtained between clinical, radiological findings and results of immunostaining markers. No previous studies did correlation between these parameters and results of immunostaining.

Diagnosis of ACC depends on the morphological appearance of acinar cells. For this reason, $a$-amylase was being used but its expression in ACC is not frank as reported previously, hence DOG1 has been evoked [25].

In the presenting study, we used DOG1, a-amylase and p63 as a panel to diagnose ACC. We found that DOG1+/a-amylase+/ p63- was present in 5 cases, DOG1+/a-amylase+/p63+ in one case and DOG1+/a-amylase-/p63- in 8 cases. These results clarify that DOG1 is superior to a-amylase in the diagnosis of ACC. However a-amylase gave positivity in 6 cases out of 14 (43\%) cases, it appears to be less sensitive for ACC. On the other hand using these 2 markers together may yield in synergistic effects on ACC diagnosis. In the presenting study 1 case was focally positive for $p 63$ and 13 cases were negative, close observation of this case revealed that this focal staining was attributed to the presence of scattered myoepithelial cells among acinar cells as a result of extensive destruction of tissue obtained by malignant tumor cells.

The high positivity of malignant acinar cells to DOG1 immunostaining in the present study is in accordance with previous studies $[6,10,11]$. The explanation of this high positivity is simplified by a symbol of an overstated acinar phenotype to a certain extent rather than gene amplification. Carles et al. [10] found that DOG1 expression in ACC were more localized in an apical serous acini and explained this observation by the fact of role of apical part of serous acini in the processing of anion channel across the cell membrane [10].

In the presenting study, we found one case showed focal weak staining for DOG1. Close observation of this case revealed 
Atta et al. Journal of Histology \& Histopathology 2015,

http://www.hoajonline.com/journals/pdf/2055-091X-2-13.pdf

doi: 10.7243/2055-091X-2-13

presence of many vacuolated cells as evidenced in the H\&E stained section. This observation was also noticed by Ousingsawat et al., [14] who accredited this observation by the presence of several factors as dispensation in the Golgi apparatus and endoplasmic reticulum, a disparity distribution of isoforms, differences in post-translational adjustment and the presence of lipid microvacuoles.

In the presenting study, we found 6 out of 14 ACC cases positive for a-amylase, this coincides with studies done by Sumitomo et al., [26] and Ihrler et al. [27]. Sumitomo et al., [26] studied the ex-pression of a-amylase in various salivary gland lesions either inflammatory or neoplastic as well as in normal salivary glands and found that the positivity of a-amylase was confined to irregularly staining serous acinar cells in normal parotid, submandibular glands, and to demilunes in sublingual glands, negative or scattered focal among neoplastic lesions and of irregular from high to low in inflammatory lesions.

Ihrler et al., [27] studied the expression of several markers beside a-amylase in ACC versus adenocarcinoma not otherwise specified and found that a-amylase was expressed weakly in ACC. Childers et al., [26] studied the reactivity of anti-amylase antibody in ACC versus cystadenocarcinoma and found that only 4 of 27 cases (13\%) of ACC cases showed reactivity and concluded that anti-amylase antibody is of limited value in the recognition of $A C C$ when light morphologicical features are insufficient for diagnosis.

In the presenting study, we found 13 out of 14 ACC cases negative for p63 antibody this coincides with studies done by Weiler et al., [28], Sams and Gnep [29] and Mitani et al. [30]. Weiler et al., [28] reported that all cases of ACC subjected to his study showed $100 \%$ p63 negativity. Sams and Gnep [29] found complete negativity in all ACC cases with p63 and demonstrated a complete lack of basal cell component manifested by negative p63 expression. All these results give more support to our presenting study.

Mitani et al., [30] studied the reciprocal p63 TA and $\Delta \mathrm{N}$ isoform expression in certain benign and malignant salivary gland tumors, of these ACC and found that salivary duct and ACC, tumors that lack myoepithelial and/or basal cells, were deficient for both isoforms and hence, all cases of ACC were negative for p63 immunostaining in contrast to tumors with myoepithelial and/or basal cell participation.

\section{Conclusion}

Application of panels composed of DOG1, a-amylase and p63 in the diagnosis of ACC is of diagnostic value, especially in cases with conflicts with other salivary gland carcinoma especially those of clear cell features. DOG1+/a-amylase+/p63- or even DOG1+/a-amylase-/p63- will support the diagnosis of ACC. Not all cases of ACC positive for a-amylase but most cases of ACC give positive staining for DOG1. So DOG1 is more superior in the diagnosis of ACC than a-amylase. Negativity of p63 in ACC cases is the rule and its positivity is the exception, hence DOG1+/a-amylase+/p63- is superior than DOG1+/a-amylase-/ p63- in ACC diagnosis.

\section{Competing interests}

The authors declare that they have no competing interests.

Authors' contributions

\begin{tabular}{|l|c|c|}
\hline Authors' contributions & ISA & FNA \\
\hline Research concept and design & $\checkmark$ & $\checkmark$ \\
\hline Collection and/or assembly of data & $\checkmark$ & $\checkmark$ \\
\hline Data analysis and interpretation & $\checkmark$ & -- \\
\hline Writing the article & $\checkmark$ & $\checkmark$ \\
\hline Critical revision of the article & $\checkmark$ & $\checkmark$ \\
\hline Final approval of article & $\checkmark$ & $\checkmark$ \\
\hline Statistical analysis & -- & $\checkmark$ \\
\hline
\end{tabular}

\section{Acknowledgement}

Much acknowledgements to prof. Ahmad Hasan Elrashedy professor of pathology, Al-Azhar university for his grateful help in both histopathological study. Also we express many thanks to Dr. Sami Assel for his valuable work and effort in the statistical study. Finally, many grateful thanks to all technician staff who shared in the immunohistochemical procedures.

Publication history

Editor: Lingyan Wang, Oregon Health \& Science University, Portland.

EIC: Giuseppe Musumeci, University of Catania, Italy.

Received: 16-Mar-2015 Final Revised: 24-Apr-2015

Accepted: 15-May-2015 Published: 22-May-2015

\section{References}

1. Oliveira P, Fonseca I and Soares J. Acinic cell carcinoma of the salivary glands. A long term follow-up study of 15 cases. Eur J Surg Oncol. 1992; 18:7-15. | PubMed

2. Cox JD, Stetz J and Pajak TF. Toxicity criteria of the Radiation Therapy Oncology Group (RTOG) and the European Organization for Research and Treatment of Cancer (EORTC). Int I Radiat Oncol Biol Phys. 1995; 31:1341-6. | Article | PubMed

3. Federspil PA, Constantinidis J, Karapantzos I, Pahl S, Markmann HU and Iro H. [Acinic cell carcinomas of the parotid gland. A retrospective analysis]. HNO. 2001; 49:825-30. | PubMed

4. Ilayaraja $V$, Prasad $H$, Anuthama $K$ and Sruthi R. Acinic cell carcinoma of minor salivary gland showing features of high-grade transformation. $J$ Oral Maxillofac Pathol. 2014; 18:97-101. | Article | PubMed Abstract | PubMed Full Text

5. Gomez DR, Katabi N, Zhung J, Wolden SL, Zelefsky MJ, Kraus DH, Shah JP, Wong RJ, Ghossein RA and Lee NY. Clinical and pathologic prognostic features in acinic cell carcinoma of the parotid gland. Cancer. 2009; 115:2128-37. | Article | PubMed

6. Chenevert J, Duvvuri U, Chiosea S, Dacic S, Cieply K, Kim J, Shiwarski $D$ and Seethala RR. DOG1: a novel marker of salivary acinar and intercalated duct differentiation. Mod Pathol. 2012; 25:919-29. | Article I PubMed

7. West RB, Corless $\mathrm{CL}$, Chen $\mathrm{X}$, Rubin $\mathrm{BP}$, Subramanian $\mathrm{S}$, Montgomery $\mathrm{K}$, Zhu S, Ball CA, Nielsen TO, Patel R, Goldblum JR, Brown PO, Heinrich MC and van de Rijn M. The novel marker, DOG1, is expressed ubiquitously in gastrointestinal stromal tumors irrespective of KIT or PDGFRA mutation status. Am J Pathol. 2004; 165:107-13. | Article | PubMed Abstract | PubMed Full Text

8. Miettinen M, Wang ZF and Lasota J. DOG1 antibody in the differential diagnosis of gastrointestinal stromal tumors: a study of 1840 cases. $A m$ J Surg Pathol. 2009; 33:1401-8. | Article | PubMed 
Atta et al. Journal of Histology \& Histopathology 2015,

9. Lee $\mathrm{CH}$, Liang $\mathrm{CW}$ and Espinosa I. The utility of discovered on gastrointestinal stromal tumor 1 (DOG1) antibody in surgical pathologythe GIST of it. Adv Anat Pathol. 2010; 17:222-32. | Article I PubMed

10. Carles A, Millon R, Cromer A, Ganguli G, Lemaire F, Young J, Wasylyk C, Muller D, Schultz I, Rabouel Y, Dembele D, Zhao C, Marchal P, Ducray C, Bracco L, Abecassis J, Poch $\mathrm{O}$ and Wasylyk B. Head and neck squamous cell carcinoma transcriptome analysis by comprehensive validated differential display. Oncogene. 2006; 25:1821-31. | Article | PubMed

11. Huang X, Godfrey TE, Gooding WE, McCarty KS, Jr. and Gollin SM. Comprehensive genome and transcriptome analysis of the 11q13 amplicon in human oral cancer and synteny to the 7F5 amplicon in murine oral carcinoma. Genes Chromosomes Cancer. 2006; 45:1058-69. | Article | PubMed

12. Almaca J, Tian Y, Aldehni F, Ousingsawat J, Kongsuphol P, Rock JR, Harfe $B D$, Schreiber R and Kunzelmann K. TMEM16 proteins produce volumeregulated chloride currents that are reduced in mice lacking TMEM16A. J Biol Chem. 2009; 284:28571-8. | Article | PubMed Abstract | PubMed Full Text

13. Kunzelmann K, Kongsuphol P, Aldehni F, Tian Y, Ousingsawat J, Warth $\mathrm{R}$ and Schreiber R. Bestrophin and TMEM16- $\mathrm{Ca}(2+)$ activated $\mathrm{Cl}(-)$ channels with different functions. Cell Calcium. 2009; 46:233-41. I Article I PubMed

14. Ousingsawat J, Martins JR, Schreiber R, Rock JR, Harfe BD and Kunzelmann K. Loss of TMEM16A causes a defect in epithelial Ca2+dependent chloride transport. J Biol Chem. 2009; 284:28698-703. I Article | PubMed Abstract | PubMed Full Text

15. Mills AA. p63: oncogene or tumor suppressor? Curr Opin Genet Dev. 2006; 16:38-44. I Article I PubMed

16. Livasy CA, Karaca G, Nanda R, Tretiakova MS, Olopade OI, Moore DT and Perou CM. Phenotypic evaluation of the basal-like subtype of invasive breast carcinoma. Mod Pathol. 2006; 19:264-71. | Article | PubMed

17. Varma $M$ and Jasani B. Diagnostic utility of immunohistochemistry in morphologically difficult prostate cancer: review of current literature. Histopathology. 2005; 47:1-16. | Article | PubMed

18. Edwards PC, Bhuiya T and Kelsch RD. Assessment of p63 expression in the salivary gland neoplasms adenoid cystic carcinoma, polymorphous low-grade adenocarcinoma, and basal cell and canalicular adenomas. Oral Surg Oral Med Oral Pathol Oral Radiol Endod. 2004; 97:613-9. | Article | PubMed

19. Ghioni P, Bolognese F, Duijf PH, Van Bokhoven $H$, Mantovani R and Guerrini L. Complex transcriptional effects of p63 isoforms: identification of novel activation and repression domains. Mol Cell Biol. 2002; 22:8659-68. | Article | PubMed Abstract | PubMed Full Text

20. Nylander K, Coates PJ and Hall PA. Characterization of the expression pattern of p63 alpha and delta Np63 alpha in benign and malignant oral epithelial lesions. Int J Cancer. 2000; 87:368-72. | Article | PubMed

21. Ko SB, Azuma S, Yokoyama Y, Yamamoto A, Kyokane K, Niida S, Ishiguro $\mathrm{H}$ and Ko MS. Inflammation increases cells expressing ZSCAN4 and progenitor cell markers in the adult pancreas. Am J Physiol Gastrointest Liver Physiol. 2013; 304:G1103-16. | Article | PubMed Abstract | PubMed Full Text

22. Greene FL, Page DL, Fleming ID, Fritz A, Balch, CM, Haller DG and Morrow $\mathrm{M}$ (eds). American Joint Committee on Cancer Staging Handbook. $6^{\text {th }}$ Ed. New York: Springer. 2002; 7:70-85. I Book

23. Hoffman HT, Karnell LH, Robinson RA, Pinkston JA and Menck HR. National Cancer Data Base report on cancer of the head and neck: acinic cell carcinoma. Head Neck. 1999; 21:297-309. | Article I PubMed

24. Oliveira, Roberto L, Soave, Figueiredo D, da Costa O and Paulo J. Acinic Cell Carcinoma of Parotid Gland, Report of Three Cases and Literature Review. Med Dent Cir Maxilofac. 2010; 51:5-11.

25. Childers EL, Ellis GL and Auclair PL. An immunohistochemical analysis of anti-amylase antibody reactivity in acinic cell adenocarcinoma. Oral Surg Oral Med Oral Pathol Oral Radiol Endod. 1996; 81:691-4. | Article | PubMed

26. Sumitomo S, Kumasa S, Tatemoto $Y$, Ookusa $Y$ and Mori M. Immunohistochemical localization of amylase in sialoadenitis and salivary gland tumors. J Oral Pathol. 1986; 15:381-5. | Article I PubMed
27. Ihrler S, Blasenbreu-Vogt S, Sendelhofert A, Lang S, Zietz C and Lohrs U. Differential diagnosis of salivary acinic cell carcinoma and adenocarcinoma (NOS). A comparison of (immuno-)histochemical markers. Pathol Res Pract. 2002; 198:777-83. | Article I PubMed

28. Weiler C, Reu S, Zengel P, Kirchner T and Ihrler S. Obligate basal cell component in salivary oncocytoma facilitates distinction from acinic cell carcinoma. Pathol Res Pract. 2009; 205:838-42. | Article I PubMed

29. Sams RN and Gnepp DR. P63 expression can be used in differential diagnosis of salivary gland acinic cell and mucoepidermoid carcinomas. Head Neck Pathol. 2013; 7:64-8. I Article I PubMed Abstract I PubMed Full Text

30. Mitani Y, Li J, Weber RS, Lippman SL, Flores ER, Caulin C and El-Naggar AK. Expression and regulation of the DeltaN and TAp63 isoforms in salivary gland tumorigenesis clinical and experimental findings. Am J Pathol. 2011; 179:391-9. | Article | PubMed Abstract | PubMed Full Text

\section{Citation:}

Atta IS and Al Qahtani FN. DOG1, alpha-amylase and p63 expression in acinic cell carcinoma of salivary gland; immunohistochemical, clinical and radiological study. J Histol Histopathol. 2015; 2:13. http://dx.doi.org/10.7243/2055-091X-2-13 